\title{
A new method for implanting a total artifical heart in the patient with a Fontan circulation
}

\author{
Ronald K. Woods, MD, PhD, ${ }^{\mathrm{a}}$ Robert Niebler, MD, ${ }^{\mathrm{b}}$ Steve Kindel, MD, ${ }^{\mathrm{c}}$ Todd Troshynski, MD, \\ Lyle D. Joyce, MD, PhD, ${ }^{\mathrm{e}}$ and Viktor Hraska, $\mathrm{MD}, \mathrm{PhD},{ }^{\mathrm{a}}$ Milwaukee, Wis
}

\footnotetext{
From the a Division of Pediatric Cardiothoracic Surgery, Department of Surgery, Medical College of Wisconsin and Herma Heart Institute and Children's Hospital of Wisconsin, Milwaukee, Wis; 'bivision of Pediatric Critical Care, Department of Pediatrics, Medical College of Wisconsin and Herma Heart Institute and Children's

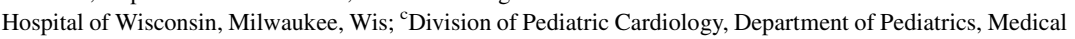
College of Wisconsin and Herma Heart Institute and Children's Hospital of Wisconsin, Milwaukee, Wis; ${ }^{\mathrm{d}} \mathrm{Di}-$ vision of Pediatric Anesthesiology, Department of Anesthesiology, Medical College of Wisconsin and Herma Heart Institute and Children's Hospital of Wisconsin, Milwaukee, Wis; 'Division of Cardiothoracic Surgery, Department of Surgery, Medical College of Wisconsin, Froedtert Hospital, Milwaukee, Wis.

No sources of funding are reported for this work.

Disclosures: Authors have nothing to disclose with regard to commercial support.

Received for publication May 3, 2018; revisions received July 13, 2018; accepted for publication Aug 1, 2018; available ahead of print Oct 22, 2018.

Address for reprints: Ronald K. Woods, MD, PhD, Herma Heart Institute and Children's Hospital of Wisconsin, 9000 W Wisconsin Ave, Milwaukee, WI 53226 (E-mail: RWoods@chw.org).

J Thorac Cardiovasc Surg 2019;157:353-5

$0022-5223 / \$ 36.00$

Copyright (C) 2018 by The American Association for Thoracic Surgery

https://doi.org/10.1016/j.jtcvs.2018.08.082
}

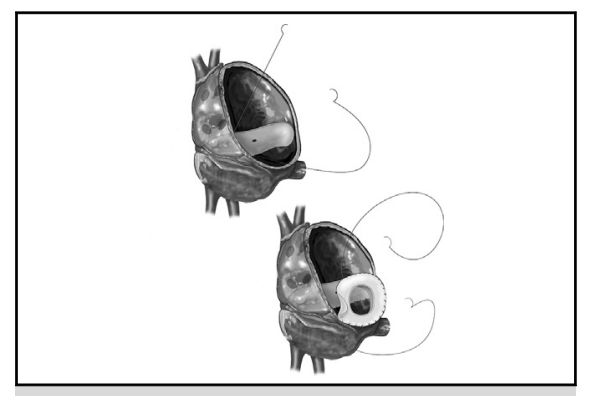

Atrial septation for total artifical heart in Fontan circulation.

\section{Central Message}

We present a new method for implanting the total artificial heart for the patient with a Fontan circulation.

See Editorial Commentary page 356
Video clip is available online.

\section{CASE}

The patient was a 29-year-old, 130-kg man with a lateral tunnel Fontan circulation listed for combined heart-liver transplant (documented cirrhosis) with worsening failure (including systolic dysfunction) despite milrinone and high-dose diuretic therapy. We had placed a ventricular assist device (HVAD; HeartWare, Framingham, Mass) to the right ventricle, resected the atrioventricular valve, and placed a short supported 6-mm GORETEX (W. L. Gore, Newark, Del) graft from the right pulmonary artery to the pulmonary venous atrium. Despite flows greater than $9 \mathrm{~L}$ (3400 rpm), there was ongoing hepatic and renal failure, severe vasoplegia, elevated central venous pressure, and inability to dialyze effectively. Extracorporeal membrane oxygenation (ECMO) support (right neck) resulted in a total flow of $12 \mathrm{~L}$ per minute and improved fluid removal. We then converted from extracorporeal membrane oxygenation and HVAD support to a salvage total artificial heart (TAH) (70 mL; SynCardia, Tucson, Ariz) procedure 1 month after the HVAD implantation. ${ }^{1}$

\section{PROCEDURE}

The critical enabling technical modification was that rather than leaving a cuff of ventricular muscle, we resected the lower atrium just above the atrioventricular valve. This allowed expansion of the resultant atrial cuff to permit atrial septation. The Fontan baffle was resected and the atrium septated with a GORETEX patch in which a 5-mm atrial septal defect was created. The inflow cuffs were then sewn to the newly created "neoannuli" with beveling to ensure that the pumps set leftward, and the cuff sewing lines offset at the level of the atrial patch and reinforced with bovine pericardial strips. Superior vena caval to atrial connection was achieved with an 18-mm GORETEX graft (Figures 1 and 2). After a day of packing, hemostasis was excellent, and the chest was closed. Despite achievement of good support (flows of 8-9 L/min) and central venous pressure in the mid teens by postoperative day 7 , the patient remained intensely vasoplegic, with persistent hepatic and renal failure. On postoperative day 10, imaging demonstrated cerebral edema and herniation, and support was withdrawn.

Another technical aspect of this case is that during cooling, the HVAD was left on but set at low rotational speed to avoid atrial hypertension and pulmonary hemorrhage (torrential collateral return noted at first case). During a brief period of circulatory arrest (at $20^{\circ} \mathrm{C}$ ) for dense scar around the atrium and pulmonary arteries (no access for some form of conventional vent or to the fenestration), a small inadvertent atriotomy allowed air entry. The aorta and HVAD outflow graft were promptly clamped, and 


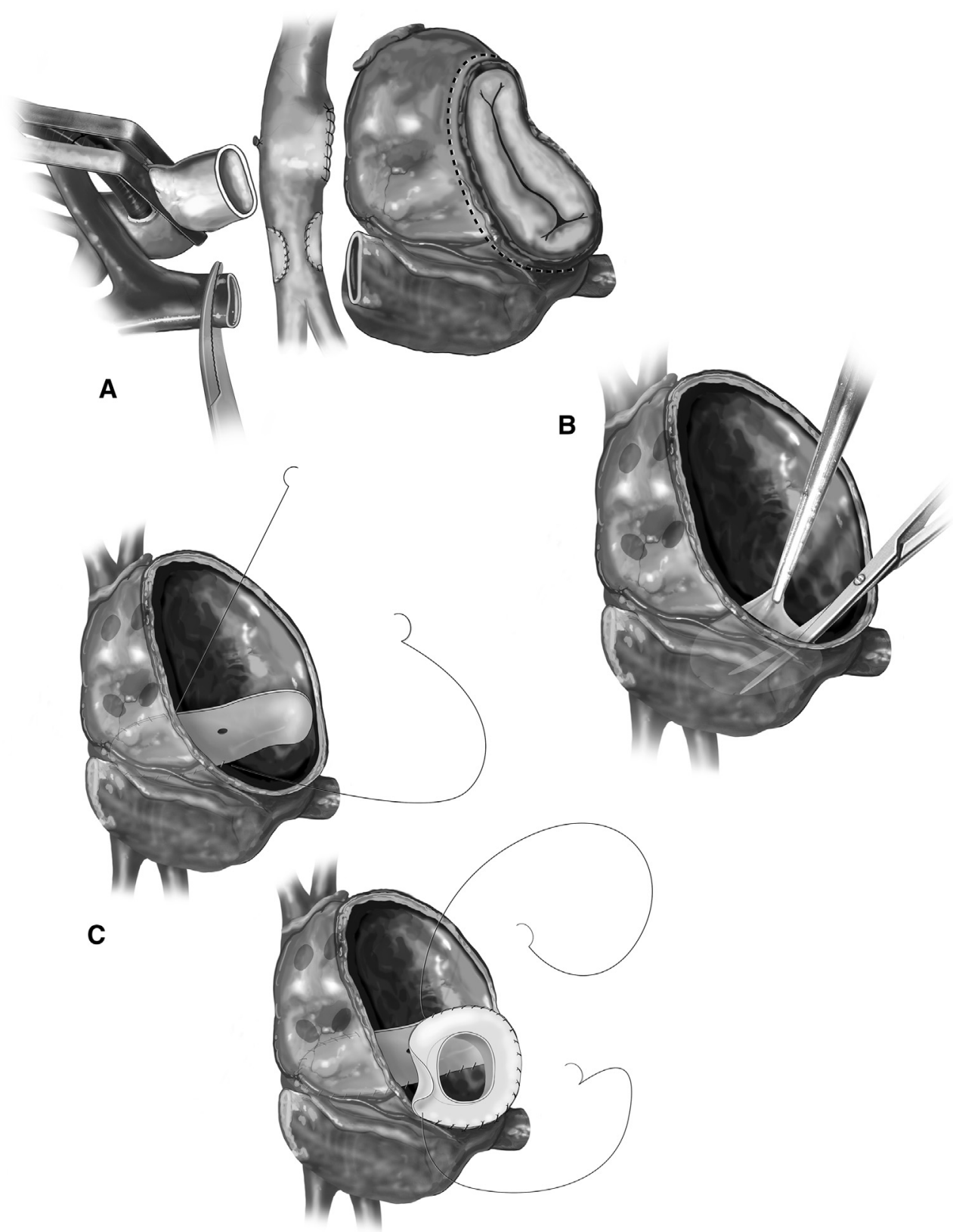

FIGURE 1. Arrangement after resection of the ventricular mass, division of the superior vena cava, and patch reconstruction of the pulmonary artery (A); resection of the lower atrium and atrioventricular valve and resection of the Fontan baffle, note the increased diameter of the atrial cuff (B); and septation of the atrial mass and attachment of the right inflow cuff $(\mathrm{C})$.

retrograde cerebral perfusion was conducted for 3 minutes. Despite the stability of cerebral oximetry, this event may have caused or contributed to the ultimate neurologic status.

\section{DISCUSSION}

The difficult judgment involved placing a systemic ventricular assist device and fenestration versus a TAH. Because of unresolved issues with creating an adequate systemic venous atrium for the TAH, we opted for the ventricular assist device and fenestration. ${ }^{2-4}$ In the absence of massive collateral return and vasoplegia, perhaps we could have avoided renal failure and achieved better fluid management and lower systemic venous pressures. In retrospect, however, given the relative ease with which adequate atrial chambers were created, we wish that we had implanted the TAH up front (Video 1). We encountered no issue with the integrity of the atrial tissue. We also observed no issues related to right-sided capacitance. The atrial septal defect created to mitigate high left atrial pressures may have helped in this regard. We believe this atrial 
A
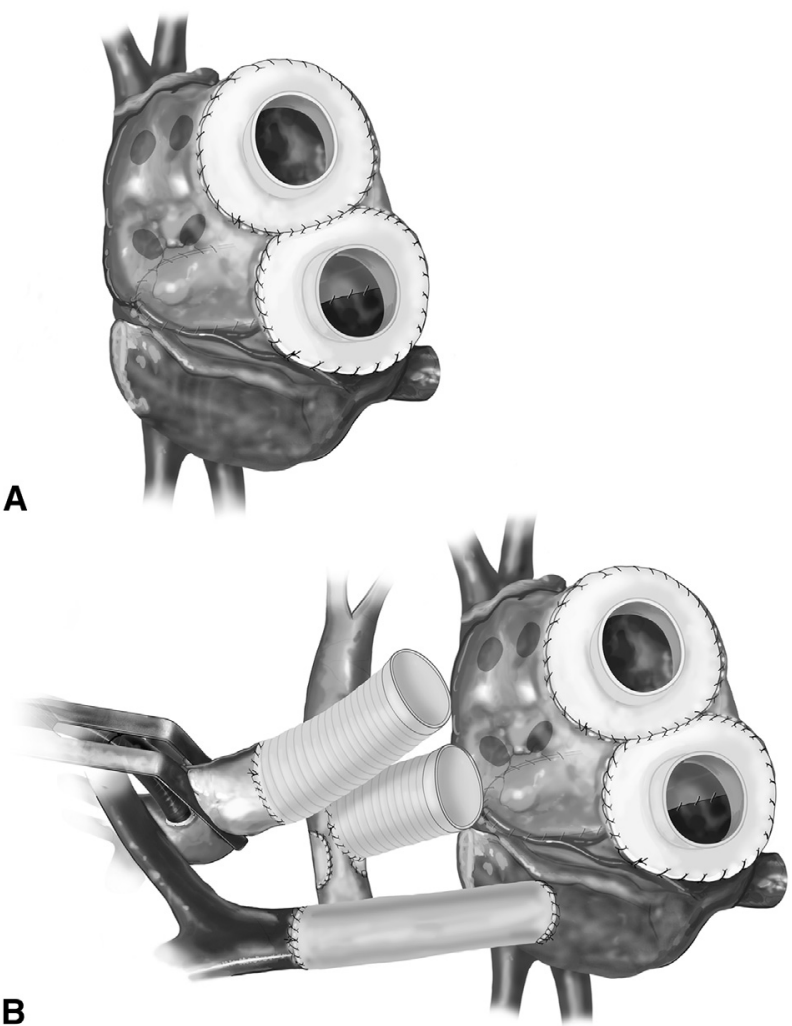

FIGURE 2. Arrangement after attachment of both inflow cuffs (A) and attachment of outflow cuffs and reconstruction of the superior vena cava (B).

cuff technique can be used for an extracardiac Fontan circulation as well-either by creating a large, nonrestrictive fenestration between the conduit and atrial wall or by resecting the conduit and performing a direct connection between the inferior vena cava and the atrium.

A second difficult judgment issue for the TAH procedure was whether or not to clamp the aorta early and risk pulmonary venous atrial hypertension and the dreaded complication of pulmonary hemorrhage or to keep the aorta open and

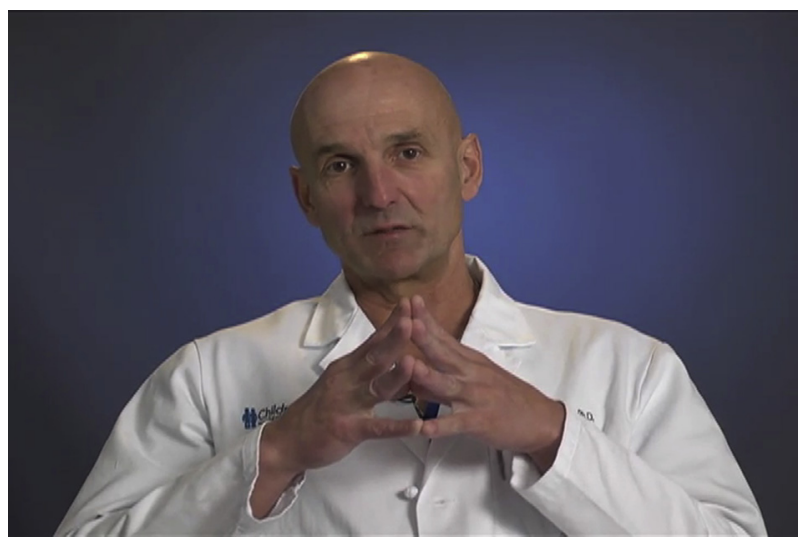

VIDEO 1. Dr Woods providing commentary on total artificial heart support for Fontan circulation failure. Video available at: https://www. jtcvs.org/article/S0022-5223(18)32476-0/fulltext.

use the ventricular assist device as a vent. Clearly, avoidance of an atriotomy and brief discontinuation of ventricular assist device support are both important.

The case was a clinical failure. We recognized the risk of mechanical support in this patient and frankly discussed the pros and cons with the patient before agreeing to provide this level of care. Nevertheless, one positive outcome is that this brave patient may have shown us a better way of doing things.

\section{References}

1. Morales D, Lorts A, Rizwan R, Zafar F, Arabia FA, Villa CR. Worldwide experi ence with the SynCardia total artificial heart in the pediatric population. ASAIO J. 2017;63:518-9.

2. Rossano JW, Goldberg DJ, Fuller S, Ravishankar C, Montenegro LM, Gaynor WJ Successful use of the total artificial heart in the failing Fontan circulation. Ann Thorac Surg. 2014;97:1438-40.

3. Woods RK, Ghanayem NS, Mitchell ME, Kindel S, Niebler RA. Mechanical circulatory support of the Fontan patient. Semin Thorac Cardiovasc Surg Pediatr Card Surg Annu. 2017;20:20-7.

4. Hoganson DM, Boston US, Gazit AZ, Canter CE, Eghtesady P. Successful bridge through transplantation with a Berlin Heart ventricular assist device in a child with failing Fontan. Ann Thorac Surg. 2015:99:707-9. 